\title{
Clark Kokich And Stone Beach: An Entrepreneurial Venture
}

Herbert E. Kierulff, (E-mail: hkierulf@spu.edu), Seattle Pacific University

\begin{abstract}
Clark Kokich is an entrepreneur who raised over \$2 million from angel investors to launch a company that manufactured and retailed custom women's swimsuits. The Stone Beach Case is the story of the venture, including an introduction and the business plan. An instructor's guide developed by the case writer is also available. This article reviews the case and the instructor's guide, and explains how to obtain a copy that may be used in the classroom.

The case has two major aspects that make it a useful teaching vehicle. First, the complete business plan (except for some lengthy details of a telephone survey) is included and can be critiqued by students for completeness, clarity, extent and type of risks, and feasibility. Second, after Clark quit his job to pursue the venture and was unable to raise sufficient start-up funds over a three month period, he was presented with an offer to return to work for his former manager, who was a division president of AT\&T at that time. But the offer had a deadline: just a few days. Clark had three options: (1) keep going; (2) take the job; or (3) pursue another venture. Examination of these options provokes lively class discussions.
\end{abstract}

\section{Introduction}

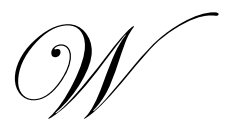

hen Clark Kokich graduated from the University of Oregon he began his career as an ad manager with the advertising department of Codaphone. His next stop was Cone Webber, an advertising agency. Here he rose to become a general manager, due in no small part to his "make it happen," non-linear approach to business. He moved to McCaw Cellular because most of his experience had been in consumer electronics, and McCaw offered stock options. When AT\&T acquired McCaw in 1995, Clark sensed that the entrepreneurial climate prevalent at McCaw was about to change because of the bureaucratic structure inherent in larger companies.

Clark had desired to become an independent entrepreneur ever since college. In interviews with the case writer it was clear that Clark demonstrated the qualities of an entrepreneur: perseverance; the need to achieve; internal locus of control; goal orientation; creativity; and so on. The only thing lacking was opportunity.

In the early 1980's, Clark's mother, Marvel Kokich, observed that off-the-rack swimsuits could not adequately take care of the wide variety of female shapes, and women found it difficult and frustrating to find suits that fit. As a result, Ms. Kokich started a new company in 1983 in Portland, Oregon: Marvel's Creations. The main objective of the company was to manufacture and distribute swimsuits that were custom designed to customers' proportions. It remained a small scale, but highly profitable operation, until she retired in 1995. During her 12 years in business Marvel developed and refined over 2,000 custom swimsuit patterns.

Clark felt certain that he could launch a $\$ 100$ million plus company based upon Marvel's Creations. He decided to quit his job at AT\&T in October, 1995 and take his two week vacation time to write a business plan and begin contacting angel investors.

Readers with comments or questions are encouraged to contact the author via email. 
I have divided this article into three sections. The first section is a summary of the business plan. The second presents the outcome of the case. The third is a summary of the major issues for discussion which are detailed in the accompanying instructor's guide.

\section{Summary of the Business Plan}

Clark's plan envisioned small retail outlets in major shopping centers around the country tied to a manufacturing facility located in Seattle, Washington. Each outlet would feature 20 to 30 of the latest styles, with a selection of 50 fabrics. Customers could mix and match sizes and styles of two-piece suits and order minor alterations. Suits would be priced competitively, starting at $\$ 60.00$, guaranteed to fit, and shipped by the date promised.

\section{Market and Competition}

The target market was the 18.8 million adult women who buy a swimming suit each year, with special emphasis on those 9.5 million who buy two or more. The latter group tended to be ages 35 to 44 , with household incomes of over $\$ 30,000$ per year. In general, these women were well educated, came from two income homes in the suburbs, and had children. There seemed to be very little variation in the demographics across geographic boundaries. The market is seasonal, with 70 percent of the suits being sold in the May-August time frame.

Clark retained Consumer Opinion Services of Seattle to do a telephone survey of 50 potential target market customers in the Puget Sound area. The survey indicated that 88 percent of the respondents found the concept very appealing. Eighty percent said that they would be somewhat likely or very likely to purchase a swimsuit from Stone Beach.

The statistical error rate was 11 percent at the 95 percent confidence interval.

At that time, four manufacturers dominated this mature market: Jantzen, Apparel Ventures, Authentic Fitness, and A.N.H. Successful companies were those that targeted the mass merchandiser or the designer ends of the market. Innovative companies with products featuring body-shaping panels and push-up bras also prospered. Traditional department stores had been losing swimwear market share to discounters and to specialty beach and swimwear stores.

The marketing plan for Stone Beach would have four key objectives:

- $\quad$ Proper positioning: The product should appeal to all customer segments and be focused on four key benefits: fit; fashion; selection; and value.

- High initial traffic: If many people visit the stores early on, word of mouth would generate high sales levels. Store location (high traffic regional malls); merchandising (wide selection); and advertising and PR (initially, radio ads) would be essential to success in this regard.

- $\quad$ Dollar volume: Sales would be maximized by selling accessories, multiple suits, and matching items.

- Long term customer relationships: Customers could be kept loyal through frequent mailings and special promotions.

\section{Operations, Management, and Finance}

Operations were to be centralized in Seattle, Washington. The management team would consist of Clark, as $\mathrm{CEO}$, and four yet-to-be-named executives. Initial financing would come from angel investors.

\section{Operations}

The retail custom swimwear shops would be less than 1000 square feet in size. Four large dressing rooms would occupy the back half of each store. The front would include the cash stand, sample suits, and available suit sizes. New stores will be opened in Portland, Oregon, and Washington State. One store would be opened in the spring and another in the summer of 1996. National expansion would occur from 1998 to 2000. 
Clark wanted to maintain control of the channel of distribution, from manufacturing through retail, to ensure quality. He chose regional malls because of his objective of encouraging high trial rates. The company would operate on open-book management principles.

Sales were projected as shown in Exhibit 1:

Exhibit 1: Sales Projections

\begin{tabular}{|c|c|c|c|c|c|}
\hline & $\begin{array}{l}\text { Year 1 } \\
1996\end{array}$ & $\begin{array}{l}\text { Year 2 } \\
1997\end{array}$ & $\begin{array}{l}\text { Year 3 } \\
1998\end{array}$ & $\begin{array}{l}\text { Year } 4 \\
1999\end{array}$ & $\begin{array}{l}\text { Year } 5 \\
2000\end{array}$ \\
\hline \multicolumn{6}{|l|}{ Store build-out schedule: } \\
\hline Beginning Stores & 0 & 2 & 10 & 30 & 60 \\
\hline New Stores & 2 & 8 & 20 & 30 & 50 \\
\hline Ending Stores & 2 & 10 & 30 & 60 & 110 \\
\hline \multicolumn{6}{|l|}{ Sales projection: $(x \$ 1,000)$} \\
\hline Volume/new store (annualized) & 440.0 & 460.0 & 480.0 & 500.0 & 520.0 \\
\hline Adjusted volume/new store* & 265.0 & 368.0 & 384.0 & 400.0 & 416.0 \\
\hline Same store sales increase & & $12 \%$ & $10 \%$ & $8 \%$ & $6 \%$ \\
\hline Existing store sales & 0.0 & 593.6 & $3,891.4$ & $12,497.1$ & $25,966.9$ \\
\hline New store sales & 530.0 & $2,944.0$ & $7,680.0$ & $12,000.0$ & $20,800.0$ \\
\hline Sales growth & & $56 \%$ & $22 \%$ & $112 \%$ & $91 \%$ \\
\hline
\end{tabular}

*Sales for new stores were adjusted at 80 percent of annualized amount. This assumes that stores are opened in the spring, which captures the peak summer and holiday volumes. To account for unforeseen problems in the start-up phase, 1996 is adjusted at 60 percent.

\section{Management}

Clark envisioned a five member board of directors (three were named in the plan), with himself as CEO. Four other management positions and their responsibilities were identified:

\section{Function}

Finance:

Retail Operations:

Construction:

Manufacturing:

\section{$\underline{\text { Responsibilities }}$}

Forecasting and budgeting Cash flow management Analysis/decision support Accounting

Information systems

Store operations and sales Sales training

Marketing and advertising Store design

Site selection Lease negotiations Project management Construction supervision

Manufacturing operations Purchasing

Shipping 
Candidates for these positions had been identified, but would be hired only after the start-up. Incentives for management would include bonuses based upon better-than- expected results against plan. Clark estimated that his team would be assembled prior to the second round of financing in early 1997.

Finance

The company was organized as an S-Corporation in Delaware in October, 1995. A total of 150,000 shares were set aside in an options pool, 150,000 shares were owned by Clark and his family, and 100,000 shares were available to be purchased in the first round by accredited investors at $\$ 10$ per share. Further financing rounds were expected. Clark estimated earnings per share to be $\$ 11.04$ in five years, giving a share value of $\$ 110.40$ assuming expected dilution and a P/E multiple of ten. The natures of the risks, which were substantial, were detailed in the plan. A summary of the proforma financials is shown in Exhibit 2:

\begin{tabular}{|c|c|c|c|c|c|}
\hline & Periods & $\begin{array}{l}\text { xhibit 2: } \\
\text { nent of } 0 \\
\text { ed Decen }\end{array}$ & $\begin{array}{l}\text { ne Beach, } \\
\text { tions--Pr } \\
31 \text { of the } \\
\text { 0's) }\end{array}$ & $\begin{array}{l}\text { Forma } \\
\text { Far indicat }\end{array}$ & \\
\hline & -.--.. & ------.P & J E C T & D-------.. & -------- \\
\hline & 1996 & 1997 & 1998 & 1999 & 2000 \\
\hline Sales & $\$ 530$ & $\$ 3,537$ & $\$ 11,572$ & $\$ 24,498$ & $\$ 46,766$ \\
\hline Cost of Sales & $\underline{106}$ & $\underline{707}$ & $\underline{2,314}$ & $\underline{4,900}$ & $\underline{9,353}$ \\
\hline Gross Profit & 424 & 2,830 & 9,257 & 19,598 & 37,413 \\
\hline Gross Margin Percentage & $80.0 \%$ & $80.0 \%$ & $80.0 \%$ & $80.0 \%$ & $80.0 \%$ \\
\hline Advertising & 160 & 300 & 579 & 1,225 & 2,338 \\
\hline Store Selling Expense & 231 & 1,238 & 4,050 & 8,574 & 16,368 \\
\hline G \& A / Overhead & 504 & 1,260 & 1,654 & 2,084 & 2,310 \\
\hline Other & $\underline{0}$ & 0 & 0 & 0 & 0 \\
\hline Total S, G, \& A & 895 & 2,798 & 6,283 & 11,883 & 21,016 \\
\hline EBITDA & $(471)$ & 32 & 2,975 & 7,716 & 16,396 \\
\hline Depreciation & 64 & 286 & 798 & $\underline{1,570}$ & $\underline{2,808}$ \\
\hline EBIT & $(535)$ & (254) & 2,176 & 6,145 & 13,588 \\
\hline Other Income/(Expense) & 0 & 0 & $\begin{array}{l}0 \\
-\end{array}$ & 0 & 0 \\
\hline EBT & $(535)$ & (254) & 2,176 & 6,145 & 13,588 \\
\hline Income Taxes & 0 & $\underline{0}$ & 762 & $\underline{2,151}$ & $\underline{4,756}$ \\
\hline Net Income & $(\$ 535)$ & $(\$ 254)$ & $\$ 1,415$ & $\$ 3,994$ & $\$ 8,832$ \\
\hline
\end{tabular}


Stone Beach, Inc.

Cash Flow Analysis - - Pro Forma

Periods ended December 31 of the year indicated (\$000's)

\begin{tabular}{|c|c|c|c|c|c|}
\hline & 1996 & 1997 & 1998 & 1999 & 2000 \\
\hline Net Income & $(\$ 535)$ & $(\$ 254)$ & $\$ 1,415$ & $\$ 3,994$ & $\$ 8,832$ \\
\hline Add Depreciation & 64 & 286 & 798 & 1,570 & 2,808 \\
\hline Change in $A / R$ & 0 & 0 & 0 & 0 & 0 \\
\hline Change in Inventory & $(10)$ & $(40)$ & $(100)$ & $(150)$ & $(250)$ \\
\hline Change in Current Liabilities & 8 & 38 & 291 & 505 & 920 \\
\hline Cash Flow from Operations & $(473)$ & 30 & 2,404 & 5,920 & 12,311 \\
\hline Capital Expenditures & 322 & 1,100 & 2,560 & 3,860 & 6,190 \\
\hline Proceeds from Stock Sale & 1,000 & 2,000 & & & \\
\hline Net Change in Cash & 205 & 920 & $(156)$ & 2,060 & 6,121 \\
\hline
\end{tabular}

Stone Beach, Inc.

Balance Sheet -- Pro Forma

As of December 31 of the year indicated (\$000's)

Cash

"Excess Cash"

Accounts Receivable

Inventory

Prepaids

Current Assets

Store Build Outs

Plant Machinery

Office Equipment

Less: Accumulated Depn.

Net Fixed Assets

$\begin{array}{lllll}1996 & 1997 & 1998 & 1999 & 2000\end{array}$

Total Assets

$\begin{array}{lllll}\$ 205 & \$ 1,125 & \$ 969 & \$ 3,209 & \$ 9,150 \\ 0 & 0 & 0 & 0 & 0\end{array}$

$\begin{array}{lllll}0 & 0 & 0 & 0 & 0 \\ 0 & 0 & 0 & 0 & 0\end{array}$

$\begin{array}{lllll}10 & 50 & 150 & 300 & 550\end{array}$

\begin{tabular}{lllll}
10 & 0 & 0 & 0 & 0 \\
\hline
\end{tabular}

$\begin{array}{lllll}0 & 1,175 & 1,119 & 3,329 & 9,700\end{array}$

\begin{tabular}{lllll}
200 & 1,000 & 3,000 & 6,000 & 11,000 \\
62 & 212 & 552 & 1,062 & 1,802 \\
60 & 220 & 440 & 790 & 1,240 \\
\hline 322 & 1,432 & 3,992 & 7,852 & 14,042 \\
64 & 351 & 1,149 & 2,720 & 5,528 \\
\hline 258 & 1,081 & 2,843 & 5,132 & 8,514
\end{tabular}

Accounts Payable

Accrued Expenses

Accrued Taxes

Other Current

Long Term Liabilities

Common Stock

Retained Earnings

\begin{tabular}{lllll}
473 & 2,257 & 3,962 & 8,461 & 18,214 \\
$\$ 3$ & $\$ 17$ & $\$ 50$ & $\$ 100$ & $\$ 183$ \\
4 & 29 & 96 & 204 & 390 \\
0 & 0 & 190 & 538 & 1,189 \\
0 & 0 & 0 & 0 & 0 \\
\hline 8 & 46 & 337 & 842 & 1,762 \\
0 & 0 & 0 & 0 & 0 \\
1,000 & 3,000 & 3,000 & 3,000 & 3,000 \\
$(535)$ & $(789)$ & 625 & 4,619 & 13,452 \\
\hline 465 & 2,211 & 3,625 & 7,619 & 16,452
\end{tabular}

Total Liabilities \& N.W.

473

2,257

3,962

8,461

18,214

ROE (Beginning of Period)

nil

nil

$64.0 \%$

$110.2 \%$

$115 . \%$ 


\begin{tabular}{|c|c|c|c|c|c|}
\hline & Period & $\begin{array}{r}\text { Sto } \\
\text { Ke } \\
\text { ed Dec }\end{array}$ & $\begin{array}{l}\text { ach, In } \\
\text { mption } \\
31 \text { of } t\end{array}$ & ar indi & \\
\hline & 1996 & 1997 & 1998 & 1999 & 2000 \\
\hline Average Unit Selling Price & 60 & 60 & 60 & 60 & 60 \\
\hline Unit Sales-New Stores & 4,420 & 6,133 & 6,400 & 6,667 & 6,933 \\
\hline Unit Sales_Existing Stores & 0 & 4,947 & 6,486 & 6,943 & 7,213 \\
\hline $\begin{array}{l}\text { COS per Unit } \\
\text { Total COS }\end{array}$ & $\begin{array}{l}12 \\
106\end{array}$ & $\begin{array}{l}12 \\
707\end{array}$ & $\begin{array}{l}12 \\
2,314\end{array}$ & $\begin{array}{l}12 \\
4,900\end{array}$ & $\begin{array}{l}12 \\
9,353\end{array}$ \\
\hline Total Capital Expenditures & 322 & 1,100 & 2,560 & 3,860 & 6,190 \\
\hline Total Inventory & 10 & 50 & 150 & 300 & 550 \\
\hline Store Selling Expense per Store & 116 & 124 & 135 & 143 & 149 \\
\hline Total & 231 & 1,238 & 4,050 & 8,574 & 16,368 \\
\hline $\begin{array}{l}\text { Advertising } \\
\text { As a Percentage of Sales }\end{array}$ & 160 & 300 & $\begin{array}{l}579 \\
5.0 \%\end{array}$ & $\begin{array}{l}1,225 \\
5.0 \%\end{array}$ & $\begin{array}{l}2,338 \\
5.0 \%\end{array}$ \\
\hline
\end{tabular}

\section{Outcome and Issues for Class Discussion}

Clark continued with the venture, raising $\$ 750,000$ from 20 investors in 1996, and another $\$ 1.4$ million in 1997 for expansion. The case presents at least four worthwhile issues for class discussion.

\section{The Outcome}

By January of 1996, three months after he had quit his job, Clark had been able to raise only $\$ 40,000$ from one investor. He had spoken to dozens of potential investors, and they liked his idea but were reluctant to invest.

At that point he received a call from his former superior at McCaw, now president of an AT\&T Division. He was invited to a Seattle Sonics basketball game; the reason for the invitation was to offer him a job with a substantial increase in pay. The president told him: "This could be like it used to be in the Cellular Division at McCaw-fun and a lot more money. Let me know in a couple of days."

Clark told the case writer that he had three options at that point: he could continue with the Stone Beach venture, go into the cellular business, or take the job at AT\&T. For him it was a "no-brainer." His heart was in entrepreneurship, and he no longer cared for the cellular industry. He met with 400 potential investors by May 1996 and raised $\$ 750,000$ from 20 of them-enough to start up.

Unfortunately, he was unable to meet his profit goals and had to shut down operations in 1998. But he exited honorably, extracting as much value as he could for his creditors and stockholders. As a result, his stockholders said they would finance another venture if Clark decided to try again.

\section{Issues for Class Discussion}

Experience with the case in class suggests that at least four issues deserve discussion, and the instructor may wish to assign these issues as questions prior to a class meeting on the case. The class seems to operate better when the discussion begins with an evaluation of the venture itself, and then moves on to a review of Clark's options. Here are the four questions, with some observations about each. More details are provided in the instructor's guide accompanying the case. 
First, does the business concept make sense? The non-technical nature of the business appeals to most students, and the female members of the class will explain very quickly the advantages of custom suits to male members who are uninformed. The telephone survey was very positive--although its limitations should be pointed out. Clark's mother, Marvel Kokich, was successful with the concept, albeit on a very limited scale.

The venture has high margins and relatively low capital requirements. Clark will be able to ensure quality because he controls the distribution channel, but his management team must be competent in all aspects of manufacturing and distribution. Locating in regional shopping malls is expensive, but competition will be limited because shopping center management does not allow two competing stores in the same center.

Second, is the presentation adequate? Students evaluating the venture wonder if Seattle is the best place for a start-up venture; worry about the phone survey and market study; are concerned that there are no women on the board of directors and that Clark has no experience in this industry and is not investing his own money in the company. They complain that the long range plan is vague and has no exit strategy explaining how the investors will get their money back.

Third, what are the risks? The proposal itself contains a long list of risk factors, including competition; problems associated with ramping up to national operations; illiquidity; financing and market uncertainty; seasonality; availability of good retail space; dependence on key personnel; and so on. Some instructors may wish to remove that section of the proposal before presenting it to students so that the students may come up with the risk factors on their own.

Finally, what are Clark's options, given the job offer? The three options were outlined above. Students may be asked what they would do under these circumstances and what they think Clark did.

\section{How to Obtain the Case}

Web sites for the case, and for the instructor's guide and the PowerPoint presentation will be available after August 31, 2002. Please contact the author for details. 
Notes 